\title{
Pembangunan Sistem Informasi Geografis Berbasis Web untuk Pemetaan Industri Kreatif Berbasis Budaya di Kota Surakarta
}

\author{
Agmalia Dwi Anggraeni dan Yanto Budisusanto \\ Jurusan Teknik Geomatika, Fakultas Teknik Sipil dan Perencanaan, Institut Teknologi Sepuluh \\ Nopember (ITS) \\ Jl. Arief Rahman Hakim, Surabaya 60111 Indonesia \\ e-mail: yanto_b@geodesy.its.ac.id, agmalia58@gmail.com
}

\begin{abstract}
Abstrak-Bila pada masa lalu sektor pertanian menjadi penggerak roda perekonomian yang dominan, pada masa kini kegiatan-kegiatan ekonomi berbasis kreativitas dan inovasi juga menjadi penggerak perekonomian yang penting. Ekonomi berbasis kreatif dipresentasikan melalui industri kreatif yang bermodalkan ide-ide kreatif, talenta dan keterampilan serta ideide terbarukan. Kota Surakarta memiliki potensi industri kreatif yang dapat diandalkan, terutama industri kreatif yang berbasis budaya. Hal itu karena, Kota Surakarta sudah memiliki sejarah panjang di bidang kreatif seperti desain. Selain itu kultur budaya yang begitu kuat membuat seni pertunjukan berkembang pesat. Industri kreatif berbasis budaya di Kota Surakarta saat ini tersebar dihampir seluruh wilayahnya, kebanyakan industri dalam skala kecil (rumahan) sampai menengah. Untuk mengetahui persebaran industri kreatif berbasis budaya di Kota Surakarta, perlu dilakukan pemetaan. Agar mendapatkan hasil yang optimal dibutuhkan keterlibatan atau partisipasi dari masyarakat dalam pemetaaan persebaran industri kreatif berbasis budaya di Kota Surakarta. Pada penelitian ini dilakukan pembangunan Sistem Informasi Geografis (SIG) berbasis Web atau yang lebih dikenal sebagai WebGIS. WebGIS merupakan aplikasi SIG yang memanfaatkan jaringan internet sebagai media komunikasi. WebGIS ini menggunakan Google Maps API sebagai peta dasar. Basis data pada WebGIS ini dibangun berdasarkan data tabular dari Dinas Industri, Dinas Kebudayaan dan Pariwisata, serta hasil penelitian lapangan. Halaman WebGIS ini dibangun dengan membuat script yang tampil pada localhost. Basis data dan script halaman di-import ke dalam hosting agar WebGIS dapat tampil secara online pada domain http://industri-kreatif-surakarta.com. Hasil dari penelitian ini adalah WebGIS Industri Kreatif Berbasis Budaya Kota Surakarta yang menyajikan informasi mengenai lokasi, atribut, serta industri kreatif berbasis budaya, serta dilengkapi dengan fitur untuk menambah lokasi dan atribut, memperbaiki atribut, dan mencari industri kreatif berbasis budaya.
\end{abstract}

Kata Kunci-Industri kreatif berbasis budaya, Kota Surakarta, WebGIS

\section{PENDAHULUAN}

$S_{t}^{\mathrm{T}}$ TRUKTUR perekonomian dunia terus mengalami transformasi dengan cepat seiring dengan pertumbuhan ekonomi, dari yang tadinya berbasis sumber daya alam (SDA) sekarang menjadi berbasis SDM, dari era pertanian ke era industri dan informasi [4]. Alvin Toffler [7] dalam teorinya telah melakukan pembagian gelombang peradaban ekonomi ke dalam tiga gelombang. Gelombang pertama adalah gelombang ekonomi pertanian. Kedua, gelombang ekonomi industri. Ketiga adalah gelombang ekonomi informasi. Kemudian diprediksikan gelombang keempat adalah gelombang ekonomi kreatif dengan berorientasi pada ide dan gagasan kreatif. Ekonomi kreatif yang direpresentasikan melalui industri kreatif yang bermodalkan ide-ide kreatif, talenta dan keterampilan serta ide-ide terbarukan, telah menjadi penopang perekonomian suatu negara. Definisi industri kreatif di Indonesia seperti yang tertulis dalam Buku Pengembangan Ekonomi Kreatif Indonesia 2025 yang dikeluarkan Kementerian Perdagangan RI [3] adalah industri yang berasal dari pemanfaatan kreativitas, ketrampilan serta bakat individu untuk menciptakan kesejahteraan serta lapangan pekerjaan melalui penciptaan dan pemanfaatan daya kreasi dan daya cipta individu tersebut.

Kota Surakarta merupakan salah satu kota besar di Indonesia yang dengan jumlah penduduk 585.486 jiwa [1]. Sebagai sebuah daerah, Kota Surakarta memang tidak memiliki lahan pertanian dan sejak dulu mengandalkan sektor jasa dan perdagangan. Akan tetapi, Kota Surakarta dinilai memiliki potensi yang besar untuk pengembangan industri kreatif. Kota Surakarta masuk dalam peta pusat industri kreatif di Pulau Jawa. Hasil penelitian Kantor Bank Indonesia (KBI) Kota Surakarta bersama Pusat Studi Penelitian dan Pengembangan Manajemen dan Bisnis (PPMB) Universitas Muhammadiyah Kota Surakarta (UMS) tahun 2010 mengungkapkan, Kota Surakarta berpotensi di tiga subsektor industri kreatif, yakni kerajinan, fashion, dan seni pertunjukan. Menurut David Wijaya, Ketua FEDEP (Forum Economy Development \& Employment Promotion) Kota Surakarta, "Kota Surakarta punya potensi besar di bidang ekonomi kreatif. Sebab sudah memiliki sejarah panjang di bidang kreatif seperti desain. Selain itu kultur budaya yang begitu kuat membuat seni pertunjukan berkembang pesat. Sehingga muncul seniman yang mengembangkan seni pertunjukan dalam berbagai versi [6]. Dengan penjelasan tersebut, dapat diketahui bahwa Kota Surakarta memiliki potensi industri kreatif berbasis budaya yang dapat diandalkan.

Industri kreatif di Kota Surakarta kebanyakan industri dalam skala kecil (rumahan) sampai menengah. Untuk mengetahui persebaran industri kreatif berbasis budaya di 
Kota Surakarta, perlu dilakukan pemetaan. Agar mendapatkan hasil yang optimal dibutuhkan keterlibatan atau partisipasi dari masyarakat dalam pemetaaan persebaran industri kreatif berbasis budaya di Kota Surakarta.

SIG adalah kumpulan yang terorganisir dari perangkat keras komputer, perangkat lunak, data geografis dan personil yang dirancang secara efisien untuk memperoleh, menyimpan, mengupdate, memanipulasi, menganalisis, dan menampilkan semua bentuk informasi yang bereferensi geografi [2], [5]. Sedangkan, Sistem Informasi Geografis (SIG) berbasis Web atau yang lebih dikenal sebagai WebGIS merupakan aplikasi SIG yang memanfaatkan jaringan internet sebagai media komunikasi.

Pada penelitian ini dilakukan pembuatan Sistem Informasi Geografis (SIG) berbasis $W e b$ atau yang lebih dikenal sebagai WebGIS. Dengan adanya WebGIS, masyarakat serta pelaku industri kreatif berbasis budaya di Kota Surakarta mampu berpartisipasi dalam mengembangkan WebGIS tersebut. Selain itu, WebGIS ini akan memberikan informasi kepada masyarakat serta pelaku bisnis tentang industri kreatif berbasis budaya di Kota Surakarta.

\section{METODOLOGI PENELITIAN}

\section{A. Lokasi Penelitian}

Kota Surakarta terletak antara $110^{\circ} 45^{\prime} 15^{\prime \prime}$ dan $110^{\circ} 45^{\prime} 35^{\prime \prime}$ Bujur Timur dan antara $7^{\circ} 36^{\prime}$ dan $7^{\circ} 56^{\prime}$ Lintang Selatan. Kota Surakarta berbatasan di sebelah utara dengan Kabupaten Boyolali, sebelah timur dengan Kabupaten Karanganyar, sebelah selatan dengan Kabupaten Sukoharjo dan di sebelah Barat dengan Kabupaten Sukoharjo. Luas wilayah Kota Surakarta mencapai $44,04 \mathrm{~km}^{2}$ yang terbagi dalam 5 kecamatan, yaitu: Kecamatan Laweyan, Serengan, Pasar kliwon, Jebres dan Banjarsari.

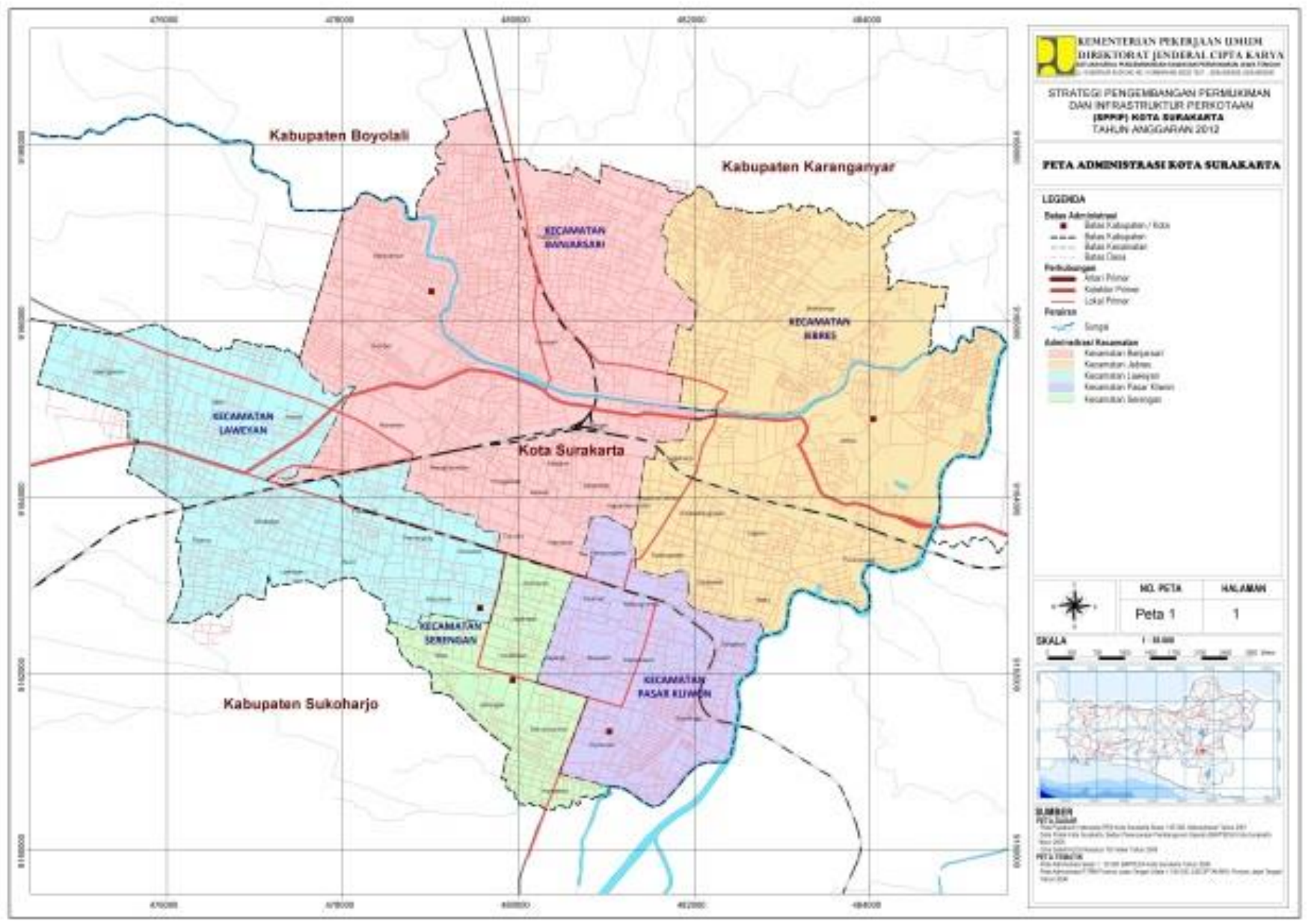

Gambar 1. Lokasi penelitian

(Sumber : Badan Perencanaan dan Pembangunan Daerah)

\section{B. Data}

Data yang digunakan dalam penelitian ini adalah:

1. Data spasial berupa peta online dari Google Maps dan hasil koordinat dari GPS Handheld.

2. Data non-spasial yang digunakan adalah data primer (survei lapangan) dan data sekunder dari Dinas
Perindustrian dan Perdagangan, Pariwisata dan Kebudayaan, Dinas Koperasi dan UMKM.

3. Foto objek sebagai dokumentasi.

\section{Peralatan}

Peralatan yang digunakan dalam penelitian ini adalah:

1. Perangkat keras (hardware)

a. Laptop 

b. Printer
c. Kamera
d. GPS Handheld

2. Perangkat lunak (software)

a. Google Maps API untuk penyedia layanan peta online

b. Global Mapper untuk konversi format data koordinat

c. Microsoft Office untuk pembuatan laporan

d. Microsot Excel untuk pengumpulan basis data awal

e. Microsoft Visio untuk pembuatan diagram alir, diagram use-case, dan diagram ERD

f. Notepad ++ untuk pembuatan script

g. XAMPP untuk mengkonfigurasikan Web-Server apache, PHP, dan MySQL

h. PhpMyAdmin untuk penyimpanan basis data

\section{Pengolahan Data}

Pengolahan data pada penelitian diawali dengan pembuatan basis data sesuai dengan rancangan yang telah dibuat serta pembuatan template Google Maps API, setelah itu pembuatan script yang nantinya script ini akan di-import pada hosting dan akan tampil secara online pada domain (alamat web) http://industri-kreatif-surakarta.com

\section{HASIL DAN PEMBAHASAN}

\section{A. Pembuatan Basis data}

Basis data dibuat menggunakan perangkat lunak open source PHPMyAdmin. Karena PHPMyAdmin mendukung operasi MySQL, maka model data yang digunakan untuk membuat basis data adalah model data relasional. Sehingga terdapat tabel relasi antar tabel entitas yang saling berhubungan.

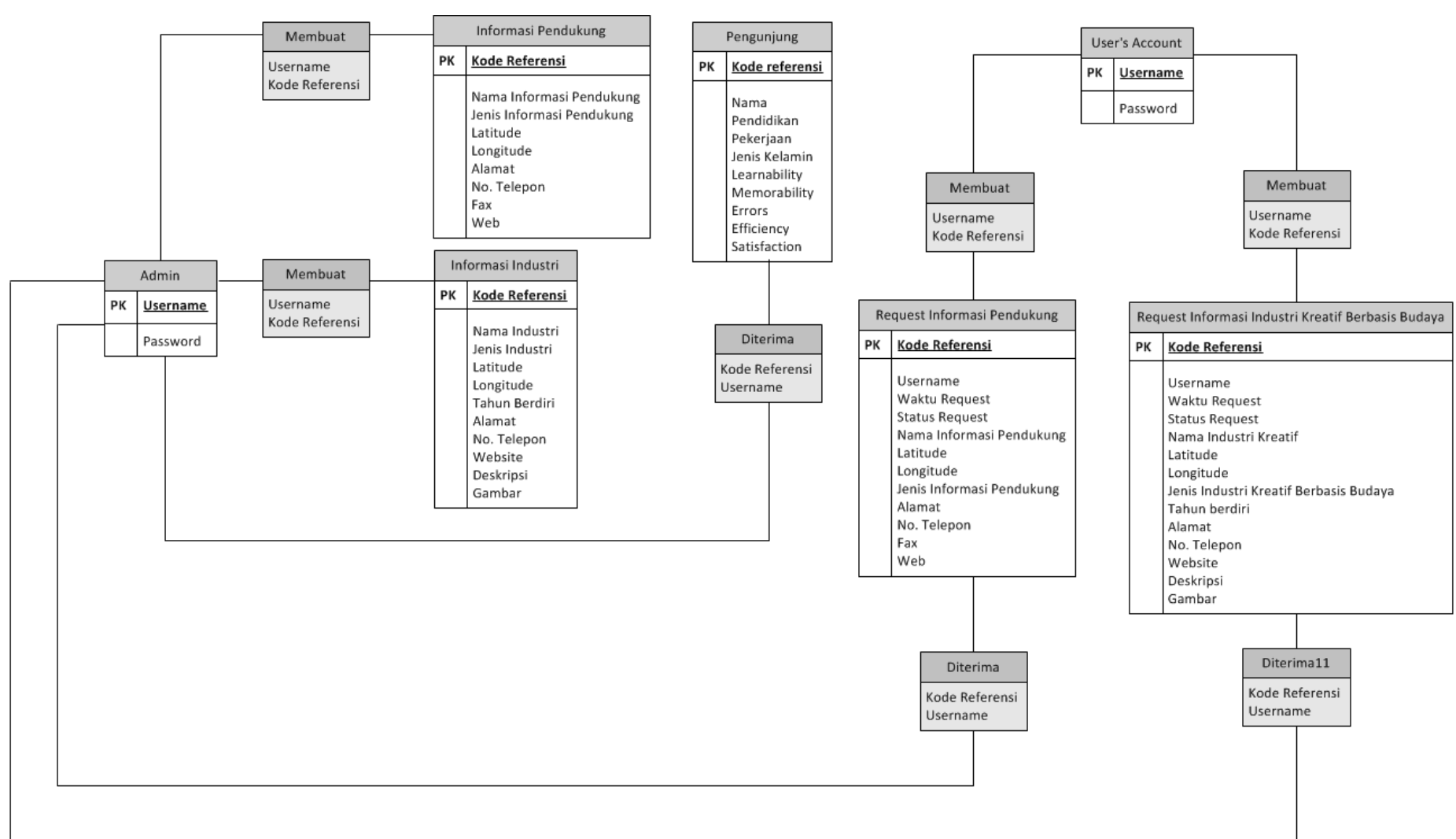

Gambar 2. Model relasional basis data

\section{B. Pembuatan Template Google Maps API}

Template Google Maps API merupakan kode (javascript ditambah html) awal yang disediakan oleh Google untuk memudahkan pengguna dalam mengembangkan peta sesuai dengan keinginan pengguna.

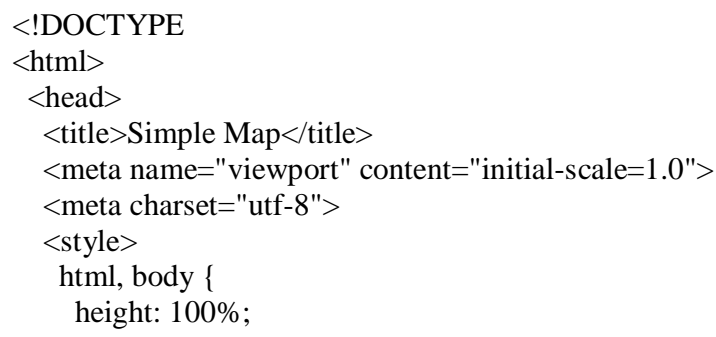

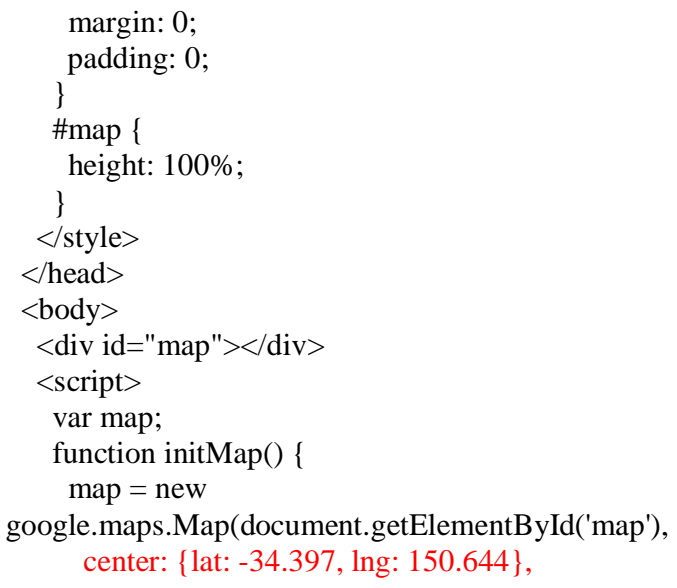




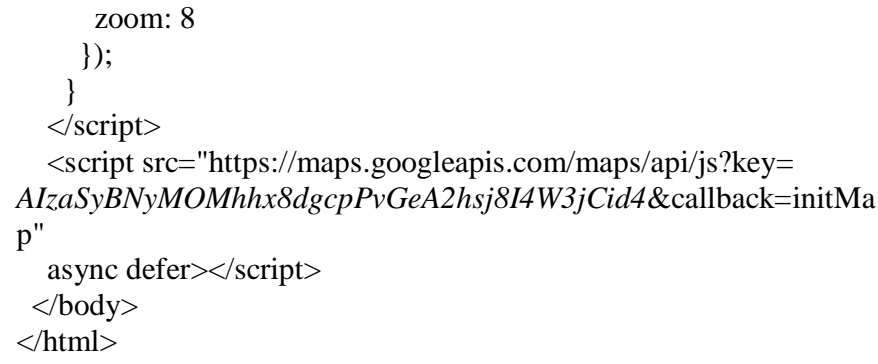

Perhatikan pada script yang menunjukkan titik koordinat

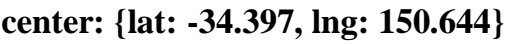

dimodifikasi menjadi var latLng = new google.maps.LatLng(-7.5747991,110.82

Fungsi var tersebut digunakan agar memberikan kemudahan bagi data koordinat yang dimasukkan oleh pengguna sehingga koordinat bersifat dinamis. Fungsi nilai center (7.5747991,110.8202274) untuk menampilkan Kota Surakarta pada peta.

\section{Tampilan Halaman WebGIS}

WebGIS ini akan tampil secara online pada domain (alamat web) http://industri-kreatif-surakarta.com terdiri dari halamanhalaman antara lain halaman utama, login, daftar, admin, tambah informasi, perbaiki informasi, detail informasi.

- Halaman Utama

Halaman utama terdiri dari 3 konten yaitu Selamat Datang, Frequently Asked Question (F.A.Q), dan peta. Konten selamat datang berisikan sekilas informasi dari tujuan pembangunan website ini. Pada sub-halaman selamat datang juga terdapat tombol yang akan mengarah ke peta dan F.A.Q.

Konten F.A.Q, berisikan tujuan serta cara pengoperasian dari website ini. F.A.Q terdiri atas pertanyaan dan jawaban yang akan sering dipertanyakan oleh pengguna pemula. Serta pada F.A.Q, pengguna dapat mengajukan pertanyaan kepada admin melalui fitur pertanyaan lain.

Konten peta berisikan peta serta fitur-fitur yang berfungsi untuk menampilkan informasi pada peta. Adapun fitur-fitur tersebut yaitu pencarian, pencarian berdasarkan tahun, pencarian berdasarkan jenis. Selain itu terdapat tambah lokasi serta legenda dari simbol yang dipakai. Pengguna dapat melihat rincian informasi dari industri dengan klik industri pada peta dan akan muncul cloud lalu klik detail.

\section{Selamat Datang!}

Website Industri Kreatif Surakarta merupakan suatu Sistem Informasi Geografis berbasis Website yang dirancang untuk memberikan informasi mengenai industri kreatif berbasis budaya yang terdapat di Kota Surakarta kepada masyarakat. Melalui website ini diharapkan mampu menjadi sarana promosi terhadap industri kreatif di Kota Surakarta serta mengajak masyarakat untuk dapat berpartisipasi dalam pemetaan industri kreatif berbasis budaya di Kota Surakarta dan menjadi sistem kontrol dalam pengelolaan industri kreatif berbasis budaya di Kota Surakarta.

Informasi lebih lanjut dapat dilihat di F.A.Q (Penting Untuk Dibaca) atau menghubungi Contact

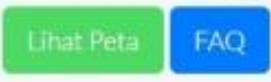

Gambar 3. Konten selamat datang

\section{Frequently Asked Questions (F.A.Q)}

$$
\text { 1. Apakah yang dimaksud dengan industri kreatif? }
$$

Definisi industri kreatif di Indonesia seperti yang tertulis dalam Buku Rencana Pengembangan Ekonomi Kreatif Indonesia 2009-2015 yang dikeluarkan Kementerian Perdagangan RI (2008) adalah industri yang berasal dari pemanfaatan kreativitas, ketrampilan serta bakat individu untuk menciptakan kesejahteraan serta lapangan pekerjaan melalui penciptaan dan pemanfaatan daya kreasi dan daya cipta individu tersebut.

\footnotetext{
2. Apakah yang dimaksud dengan industri kreatif berbasis budaya?

3. Ada berapa macam subsektor industri kreatif dalam website ini?

4. Apakah yang dimaksud dengan subsektor fashion?

5. Apakah yang dimaksud dengan subsektor kriya?

6. Apakah yang dimaksud dengan subsektor seni pertunjukan?

7. Bagaimana cara berpartisipasi dalam website ini?
}

\section{Lihat Peta Pertanyaan Lain}

Gambar 4. Konten F.A.Q 


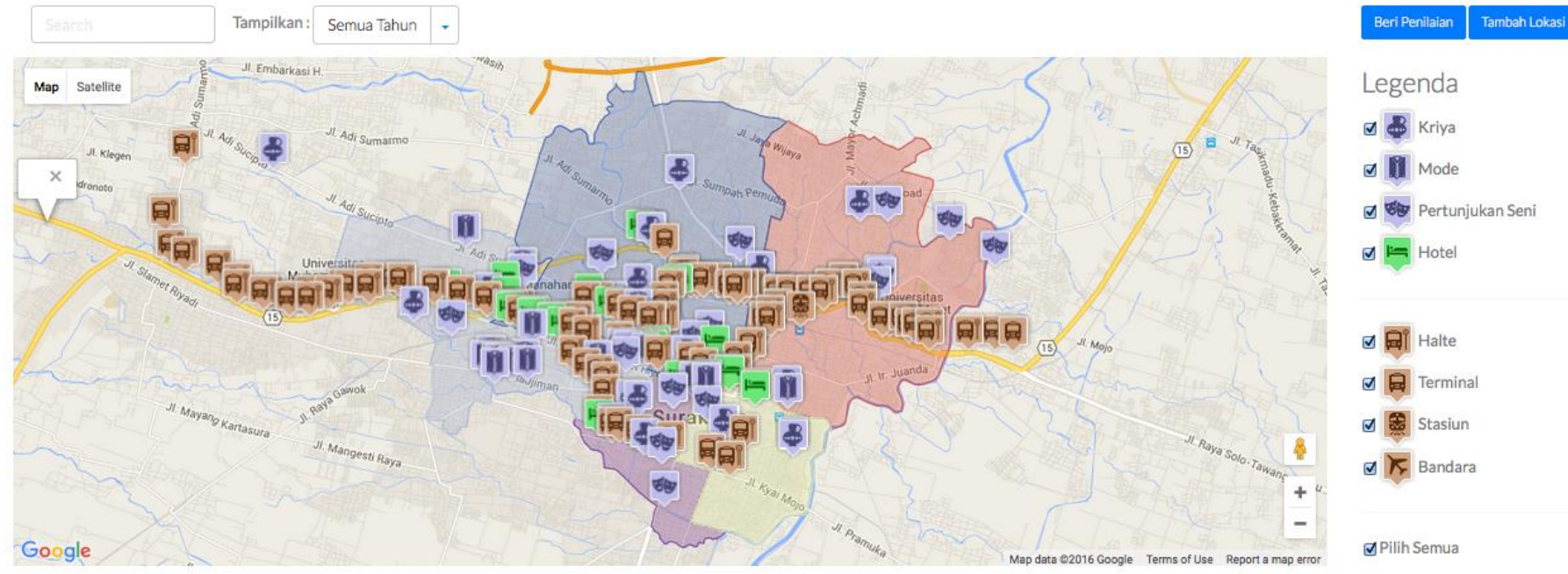

Gambar 5. Konten peta

- Halaman Login

Admin dan pengguna login pada halaman login yang sama, username dan password yang dimasukkan nantinya yang akan menentukan peran (admin atau pengguna). Sebelum pengguna login, pengguna harus membuat akun terlebih dahulu dengan cara mendaftarkan diri pada halaman daftar. Pada menu login juga terdapat tombol untuk ke halaman daftar.

- Halaman Daftar

Pengguna dapat membuat akun dengan cara melakukan pendaftaran pada halaman daftar. Halaman daftar terdiri dari kotak teks email, username, dan password yang harus diisi oleh pengguna.

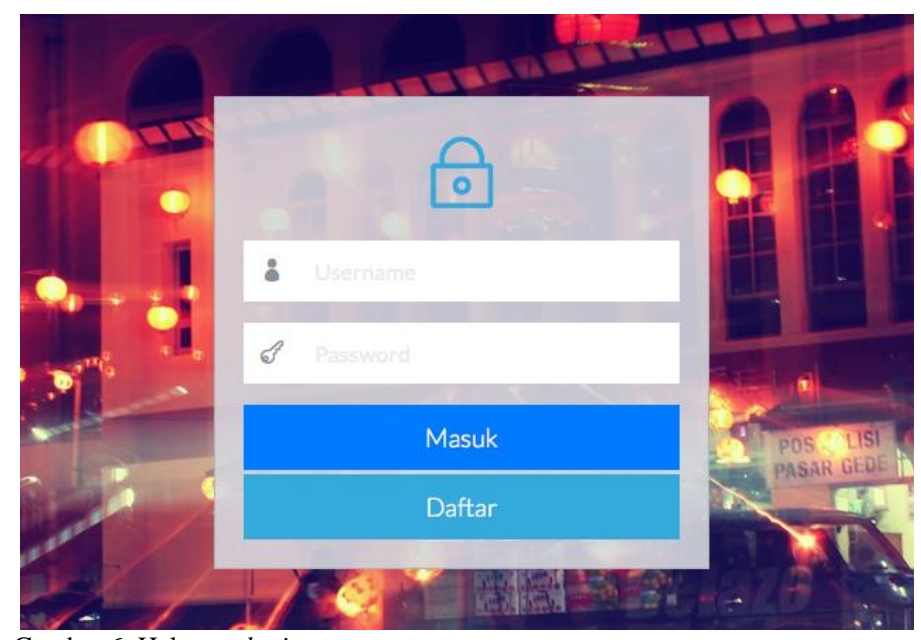

Gambar 6. Halaman login

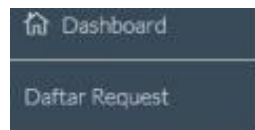

Daftar Wisata Aktif No Nama Alamat

Gambar 8. Sub-halaman daftar industri dan informasi pendukung aktif

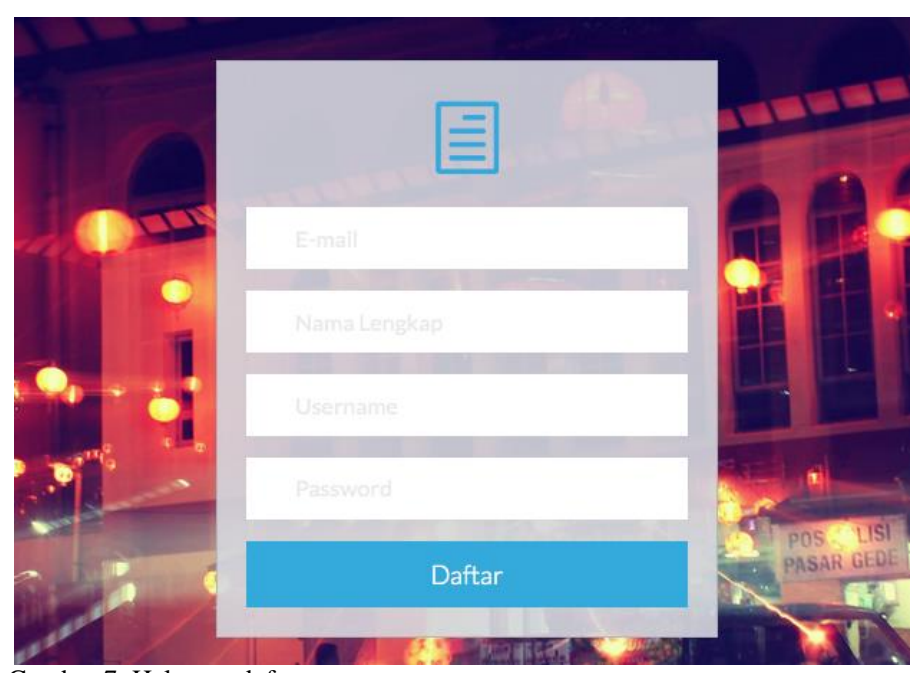

Gambar 7. Halaman daftar

\section{- Halaman Admin}

Pada website ini admin bertugas membuat informasi industri serta informasi pendukung lainnya dan melakukan verivikasi data yang diberikan oleh pengguna. Admin dapat masuk ke halaman admin untuk melakukan tugasnya. Halaman admin berisikan sub-halaman dashboard dan daftar request dari pengguna.

Sub-halaman dashboard berisikan daftar informasi industri dan informasi pendukung yang sedang aktif atau dipublikasikan pada website.

Sub-halaman daftar request merupakan industri ataupun informasi pendukung yang diberikan oleh pengguna melalui fitur tambah lokasi. 


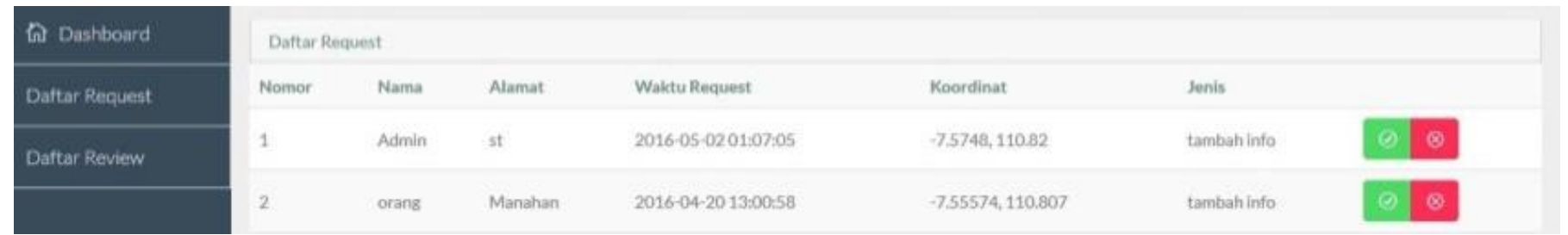

Gambar 9. Sub-halaman daftar request dari pengguna

- Halaman Tambah Informasi

Pengguna dapat menambah informasi dengan klik tomol tambah informasi pada konten peta di halaman utama. Halaman tambah informasi terdiri dari peta online Google Maps dan kotak teks longitude, latitude, jenis industri, nama industri, tahun berdiri, alamat, telepon/fax, website, deskripsi, foto. Kotak teks longitude dan latitude akan terisi otomatis sesuai dengan lokasi yang dipilih pengguna pada peta online Google Maps.

- Halaman Perbaiki Informasi

Pengguna dapat memperbaiki informasi yang sudah ada dengan klik perbaiki pada halaman detail informasi. Pada dasarnya halaman perbaiki informasi terdiri dari kotak teks yang sama seperti halaman tambah informasi, hanya saja kotak teks pada halaman ini sudah terisi oleh informasi yang diberikan sebelumnya.

\section{- Halaman Detail Informasi}

Halaman detail informasi berisikan rincian informasi dari industri. Halaman ini terdiri dari tiga konten yaitu konten gambar, peta online Google Maps, dan atribut dari industri. Pengguna dapat mengetahuo posisi atau lokasi dari industri ditunjukan pada konten peta online Google Maps. Apabila menurut pengguna informasi yang ada pada website ini salah atau kurang, maka pengguna dapat memperbaikinya dengan klik tombol sarankan perbaikan. Tombol ini akan menuju halaman perbaiki informasi dengan syarat pengguna sudah login terlebih dahulu.
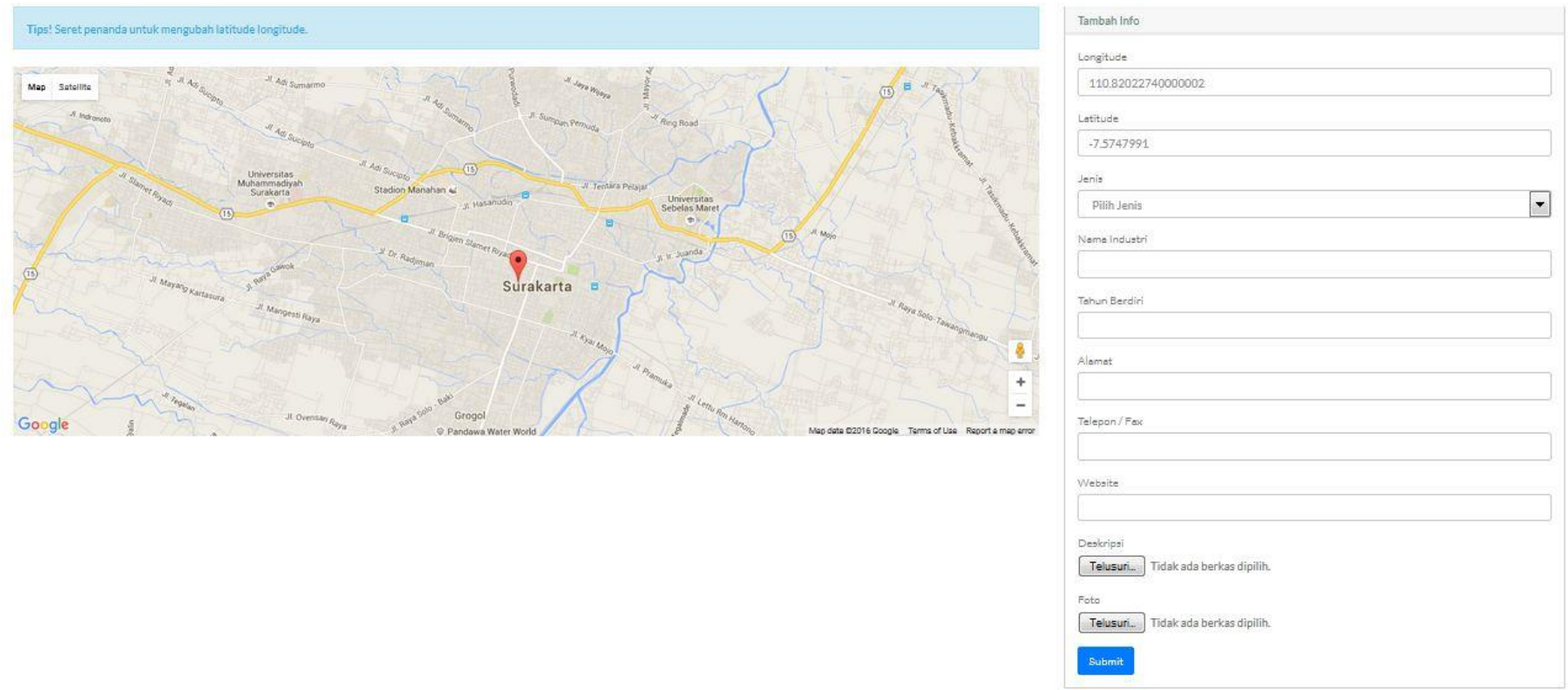

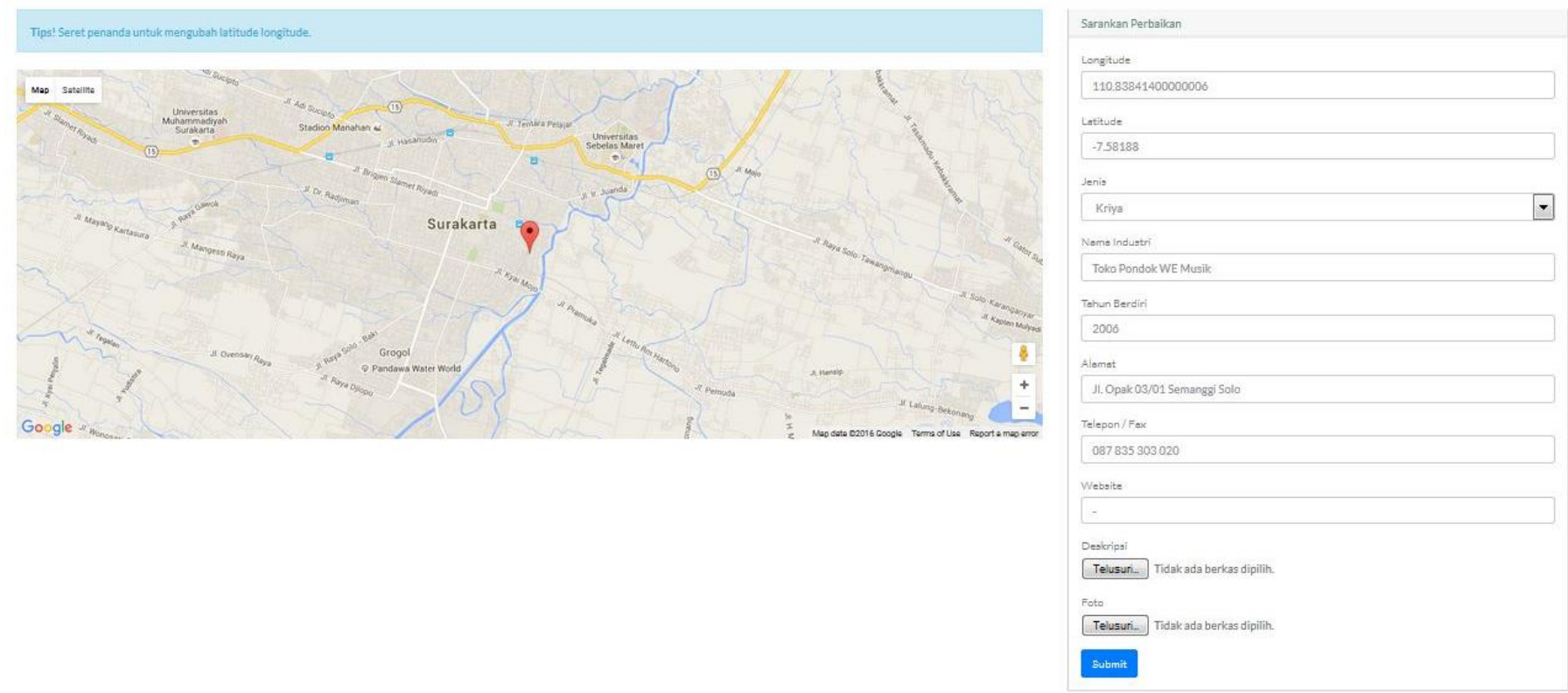

Gambar 11. Halaman perbaiki informasi

\section{Informasi Detail}

\section{Gambar}

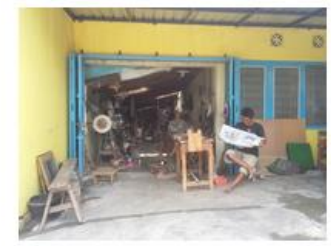

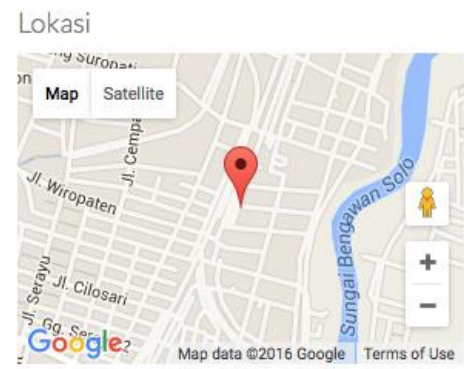

Gambar 12. Halaman detail informasi

\section{KESIMPULAN}

WebGIS Industri Kreatif Berbasis Budaya di Kota Surakarta ini memiliki fitur-fitur yang akan memberikan informasi kepada masyarakat serta pelaku bisnis tentang industri kreatif berbasis budaya di Kota Surakarta, seperti fitur pencarian dan menampilkan berdasarkan jenis serta tahun berdiri industri.

Selain itu masyarakat serta pelaku industri kreatif berbasis budaya di Kota Surakarta mampu berpartisipasi dalam melengkapi informasi pada WebGIS ini, melalui fitur tambah informasi dan perbaiki informasi.

\section{DAFTAR PUSTAKA}

[1] Badan Pusat Statistik Surakarta, 2014. Kota Surakarta Dalam Angka. Surakarta: Badan Pusat Statistik.

[2] ESRI, 1990. Understanding GIS: The ArcInfo Method. Redlands: CA: Environmental System Research Institute.

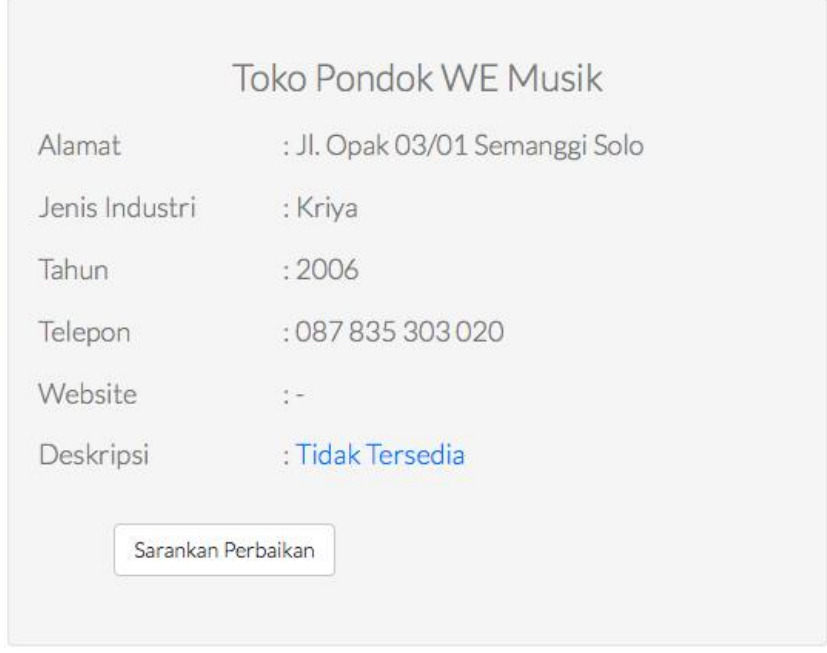

[3] Kementrian Perdagangan RI, 2008. Pengembangan Ekonomi Kreatif Indonesia 2025. Jakarta: Kementrian Perdagangan RI.

[4] Kementrian Perdagangan RI, 2011. Karya Indonesia (Vol. 3). Jakarta: Kementrian Perindustrian RI.

[5] Prahasta, E., 2014. Sistem Informasi Geografis : Konsep-konsep Dasar (Perspektif Geodesi \& Geomatika). Bandung: Informatika.

[6] Primartantyo, U., Sept. 2014. Solo Didorong Jadi Kota Ekonomi Kreatif, <URL: http://nasional.tempo.co/read/news/2014/09/23/058609175/solodidorong-jadi-kota-ekonomi-kreatif $>$. Dikunjungi pada tanggal 31 Desember 2015.

[7] Toffler, A., 1980. The Third Wave. United States: Bantam Books. 